\title{
THE CHALLENGES OF TRANSNATIONAL ONLINE LEARNING
}

\author{
Richard A Skinner \\ Senior Vice President for Programs and Research \\ Association of Governing Boards of Universities and Colleges
}

\begin{abstract}
Globalization is enabling transnational provision of post-secondary education. The leadership of higher education needs to attend to issues of quality and accreditation.
\end{abstract}

\section{KEYWORDS}

Quality, Governments, Asynchronous Learning, Leadership, Acceptance, Faculty

\section{INTRODUCTION}

A convergence of trends - some technological, others political and economic —is increasing awareness of just how porous national boundaries are with respect to regulating the distribution and availability of tertiary education. The presence of universities from nations of the developed world in developing countries is now commonplace, and it is increasingly possible to find developed nations' colleges and universities in other developed countries [1]. Depending on one's definition of "multi-national", transnational providers of post-secondary education are either now operating or will soon do so.

These developments reflect the extent to which the process of globalization has affected education. The advent of the World Wide Web and the spread of information and communications technology make it practical to think of prospective learners as having a much wider array of choices among providers of post-secondary education than was previously the case. This, in turn, builds off of the general acceptance of market economy principles, including unrestricted trade in goods and services and the student as a consumer of educational services.

In April 2004, the Organization for Economic Cooperation and Development (OECD) and UNESCO began work to develop guidelines to assure quality in cross-border education. In October 2005 and most recently in January 2005, the two organizations were able to consult widely with members and produce a draft text (see http://www.oecd.org/dataoecd/34/42/34732302.pdf) to be considered by member countries and UNESCO's Executive Board. This work mirrors or, at a minimum, parallels the thrust of the Sloan Consortium. As such, a review of this and other similar works affords the Consortium's Board of Directors an opportunity to compare and contrast their approaches and concerns for quality with those of colleagues.

The review presented here was facilitated by discussions with leaders of the Sloan Consortium when the organization held its annual meeting of directors at Royal Roads University in Victoria, British Columbia, Canada, where the author then served as vice chancellor and president. 


\section{AN “OUTSIDER’S” VIEW OF THE SLOAN CONSORTIUM’S APPROACH TO QUALITY}

Sloan-C publications present an approach to asynchronous learning that is generally upbeat with respect to the potential this kind of teaching and learning offers and modest insofar as the impact likely to result. Sloan-C's quality framework consists of five "pillars" - learning effectiveness, cost effectiveness and institutional commitment, access, faculty satisfaction, and student satisfaction (see the figure below) —and invokes the criterion of "at least as good as" or "comparable to" conventional education to assess learning effectiveness.

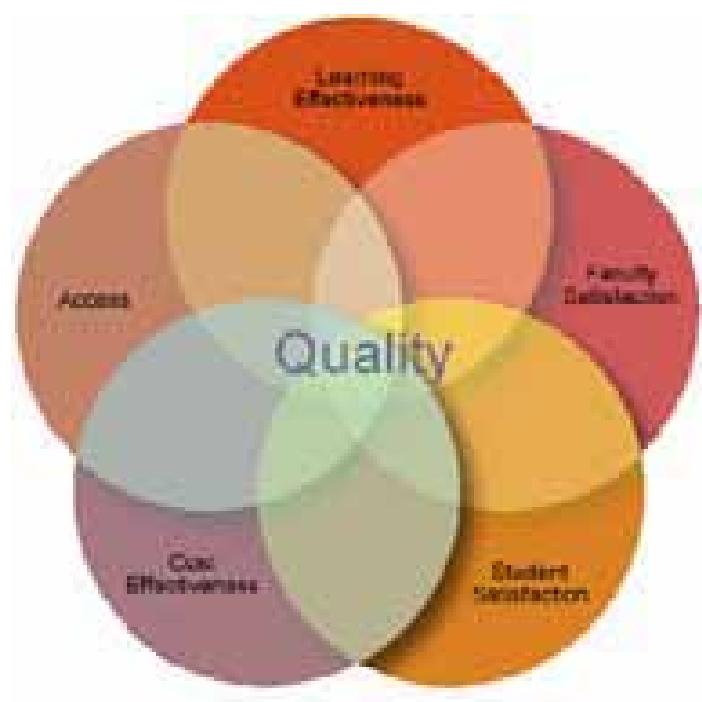

Figure 1. Sloan Consortium Quality Framework and Five Quality Pillars

For the Sloan Consortium, responsibility for the quality of learning lies with the "learning organization" or institution and is cast in terms of continuous quality improvement. The presumption is that learning organizations are concerned for the quality of the education they provide or, at a minimum, sensitive to the standards of quality required for accreditation and re-accreditation. This perspective most likely reflects the membership of the Sloan Consortium, which is predominantly American institutions, and these are subject to regulation by regional accrediting agencies as well as an array of specialized accrediting bodies. Canada, by contrast, has no accrediting bodies.

“Acceptance” of asynchronous learning by faculty and students is an important element of Sloan-C's approach to quality. The importance of this particular consideration increases as one considers the role academic presidents play in fostering or discouraging the adoption of new methods of instruction: i.e., generally aversive to risk and reluctant to get far out ahead of their faculty or students; hence, resistance from professors and students to new methods is likely to reinforce presidential conservatism.

Furthermore, "at least as good as" or "comparable to" standards juxtapose asynchronous learning with traditional classroom lecture or seminar formats which are the ones with which presidents are most comfortable. That the quality of teaching or learning in those conventional methods raises some question to whether meeting or surpassing those standards is, in itself, something to settle for with respect to quality. 
In addition, the age and backgrounds of most academic presidents generally mean that, as a group, they are neither especially familiar with technology nor aware of its more advanced uses in teaching and learning.

\section{OECD-UNESCO GUIDELINES ON QUALITY PROVISION IN CROSS-BORDER HIGHER EDUCATION}

Less-sanguine views of the impact of asynchronous learning are apparent in many of the public documents emerging from OECD and UNESCO. Policymakers recognize the potential of technologybased education to overcome barriers to expanded access to tertiary learning and numerous regional consortia or virtual universities (e.g., African Virtual University) have been established to exploit the potential.

Nevertheless, the perspective brought to bear to date by OECD and UNESCO also includes concern for the student-as-consumer; hence, the question is posed -

[W] hat might be done to limit the risks of students falling victims to rogue providers that offer a low-quality cross-border educational experience and qualifications of limited value? [2]

This concern stems, in part, from the recognition that asynchronous learning is something much more than digital correspondence courses and, instead, presents real challenges with respect to quality assurance.

'Borderless education' ... crosses several boundaries. The crossing of these boundaries gives rise to particular quality assurance challenges. Governments, higher education agencies and institutions are challenged by the crossing of national borders in transnational education, the crossing of organisational borders in consortia-based education, the crossing of sectoral boundaries in new educational alliances between universities and businesses and the crossing of functional boundaries made possible by developments in ICT. Virtual education can cross all these boundaries simultaneously which means that a variety of quality assurance issues need to be addressed. The challenges to quality assurance arise in part because the definitions of quality that we routinely use and the attendant quality assurance arrangements have been defined in the context of traditional categories, that is, national systems of higher education, individual institutions, higher education sectors and a seamless educational process. The emerging categories that are associated with 'borderless' and virtual education suggest a need for some redefinition of ‘quality’ and quality assurance arrangements [3].

By contrast, the Sloan-C quality framework is relatively simple and elegant, with little of the "messiness" attendant to a view of asynchronous learning as something that is happening to a country or group of countries, as opposed to something being done by institutions in a country that has been, to date, apparently impervious to foreign delivery of learning [4].

At the same time, however, the OECD-UNESCO agreement on transnational education is a voluntary, non-binding and un-enforced one that rests on the Lisbon Convention on the Recognition of Qualifications concerning Higher Education in the European Region and its very cautious but explicit acknowledgement of the principle of institutional autonomy (see the Civic Education Project, http://www.cep.org.hu/). As such, this otherwise more expansive approach to quality assurance actually 
ends up being more akin to than different from Sloan-C's framework and thus lodges responsibility for quality assurance with the institution or learning organization.

As Middlehurst and Campbell [5] note:

- UNESCO, through its Global Forum on International Quality Assurance, Accreditation and the Recognition of Qualifications, is promoting the development of principles of good practice [a la WICHE and SREB's Electronic Campus] in cross-border education, national capacity building in quality assurance and the modernizing of regional conventions on the recognition of qualifications. UNESCO has therefore both a formal, quasi-regulatory role (through its international scope and its broad governmental membership) and a less formal, guidance, capacity-building and information role.

- The OECD is aiming to be the "bridge" between the world of trade and education, improving communication and understanding and providing data about the trends in education and new forms of learning.

The Sloan-C approach seems to be quite in tune with that of the OECD.

\section{SOME PERSONAL OBSERVATIONS}

As Sloan-C has reported [6], online learning has moved from the periphery of American higher education to the mainstream. A majority of academic leaders there asserts that online learning meets and exceeds the quality of more conventional methods and formats. Such is not the case in Canada and, based on personal experience, nor is that the case elsewhere.

Just two years ago, the author and one of Sloan-C's directors were contracted with by a Middle Eastern nation's ministry of higher education to assist that country's accreditation commission in the design of licensing standards for colleges and universities seeking to offer programs online. It was made clear to us that an aim was to restrict-if not deny-access to online learning, even in the case of programs targeting expatriates, not citizens of the country.

In Canada, Canadian Virtual University (www.cvu-uvc.ca), Campus Canada (www.campuscanada.ca), and COHERE (www.cohere.ca) are multi-institutional consortia offering online learning courses and programs. There is no real Canadian counterpart to Sloan-C, so it is difficult to inventory the extent to which online learning has moved from periphery to mainstream, but the very conservative nature and strong traditionalism of Canadian higher education encourages one to think in modest terms. While distance education has a tradition in geographically-large and sparsely-populated Canada and the country ranks second to only South Korea in terms of broadband access, online learning has not achieved the scope or momentum it has in the US.

Similarly, China's and most Southeast Asian countries' universities are quite resistant to online learning. Conversations with officials in China, including officials of the Ministry of Education, often include references to online offerings in the mid-1990s that were seen as little more than text on the Web and involved some instances of fraud.

These concerns notwithstanding, the Chinese central government is insisting on expanded use of technology-based learning. The 2003-2007 Action Plan for Invigorating Education [7] calls for "the establishment of an online (or Internet-based) education public service platform ensuring sharing of both 
hardware and software resources" and "populariz[ing] the use of information technology within the teaching process in educational institutions of all types and levels." One of China's most prestigious institutions, Peking University, has elected to develop an arm's length organization, Beida Online (http://edu.beida-online.com/) to offer online courses and programs.

In the case of Uganda's Makerere University, initial discussions with Royal Roads did not emphasize use of RRU's self-built e-learning system. A week-long visit by Makerere's vice chancellor, including sitting in on both face-to-face residencies and e-learning, convinced him to focus attention on online learning as well as the content of the programs to be worked on jointly by the two institutions.

A similar outcome came about in the course of developing memoranda of agreement between Royal Roads University and three Thai institutions for delivery of RRU's Master's in Conflict Analysis and Management. In early explorations, the Thai institutions expressed strong concerns about any e-learning being included in joint undertakings. A visit to Royal Roads' campus and experience of Thai presidents, vice presidents, and deans changed those attitudes completely, and Thai faculty will be spending time this summer in Victoria gaining familiarity with the RRU e-learning platform while Royal Roads technology and instructional design staff will be visiting each of the Thai universities in advance of the Master's program’s launch in November 2005.

These and other personal experiences suggest several tentative "lessons" about quality online learning viewed from a transnational perspective:

- Developing countries' universities are generally skeptical of e-learning, initially because they perceive their nations' and their institutions' capacities for online learning to be very marginal, at best. This, in turn, increases their doubts about the efficacy and quality of learning that depends on the existence of infrastructure - technological and human.

- The average age of the professoriate in many non-Western countries and their own lack of exposure to and experience with technology cause faculty and, by extension, administrators to question whether online learning can be anywhere near "as effective" as "tried and true" lectures and seminars. Moreover, because much of the literature about e-learning focuses on the needs of the learner, some faculty view this approach as diminishing their status or at least placing them in potentially embarrassing situations where they are uncomfortable and unfamiliar with e-learning.

In China, for example, government officials speak of moving away from "teacher- and text-centred" to "learner-centred" approaches, regardless of how education is delivered. Informal discussions with Chinese university faculty suggest that this attitude has already been viewed as something of a threat to the status of faculty.

- Developed nations' universities appear to be content with applying accreditation standards, hence, peer-developed standards of quality in assessing online learning. In this sense, then, online learning has indeed, as the Sloan Consortium's most recent survey suggests, moved into the "mainstream" of North American higher education.

- Reflecting perhaps recent decades movement toward greater regional integration, European nations' post-secondary institutions seem to harbor questions about the utility of national or institutional quality assurance processes and appear to be looking to construct some transnational standards for online learning. This creates an opportunity for Sloan-C to engage European colleagues in some substantive and potentially productive discussions about how to establish and use quality standards.

- National governments in general are "encouraging” educational institutions of all types and at all levels to explore e-learning, in part it seems, because of recent large-scale investments in 
telecommunications infrastructure, including broadband. Additional motivation for government appears to be concern for (a) having more citizens able to use technology and (b) the hope that online or any other type of technology-enhanced learning can scale to absorb the numbers of students seeking access to education.

- Educators and policymakers recognize that new providers of learning are emerging which do not conform to traditional models and structures and therefore may not "fit" within existing frameworks of quality assurance. These new providers include consortia of universities, forprofit companies, and subsidiaries of universities.

- It remains unclear how national, regional and specialized accreditation processes will affect elearning content and delivery. Whereas a reasonable argument can be made that specialized accreditation in particular (i.e., AACSB, ABET, etc.) has tended to "homogenize" accredited programs, no evidence has emerged yet to indicate how this will impact online learning. Nevertheless, it is not unreasonable to expect that accreditation will have some effect and that the process may in fact ensure some degree of quality, but accreditation may also push online content toward greater similarity and, in the process, could contribute to "commoditization" of e-learning.

- As Oblinger [8] has observed, the current generation of traditional-aged students have expectations associated with their use of technology that entail services being every bit as accessible as the online content itself. Moreover, the availability of those services determines to some extent the perceived quality of the content or the online learning. Sloan-C's quality framework incorporates a concern for student acceptance of online learning that is less apparent than in other quality guidelines [9].

- Presidents do not seem to play especially visible roles in online learning. This is not surprising given the average age (55-56) and backgrounds (social sciences, humanities predominantly) of most North American university presidents. The general conservatism of most presidents could reasonably be expected to translate into something less than a strong leadership role with respect to online learning.

At the same time, the author's recent experience with academic presidents from developing countries suggests that personal exposure to and experience with online learning can influence significantly and positively the attitudes of university administrators. Quality of learning is, of course, of particular importance to presidents, but student and faculty acceptance of e-learning will likely top concern for quality, at least in their initial thinking. The fact that online learning has attracted and continues to engage serious research by academics into what constitutes effective practice may serve to allay some of the concerns of presidents.

Then and as suggested by the last few years' results from Kenneth Green's annual survey for the Campus Computing Project, presidents are apt to be concerned for their institutions' respective ability to afford to maintain and enhance the computing infrastructure of universities, particularly as online learning becomes more of a part of the mainstream. Even as hardware costs for PCs fall to triple-digit prices and servers' price tags come down, computing infrastructure costs continue to exceed what many presidents see as affordable within cost structures where salaries and benefits (not to mention basic operating and maintenance expenses) consume most of the resources of institutions.

Presidential anxiety over the quality of online learning is real since most know all too well how perceived quality of education ranks among the matters students and their families assess in making choices among institutions. That anxiety is most likely acted on in the US by presidents' involvement in accreditation and re-accreditation, processes that have not been and are not especially receptive to online learning to date. In that regard, then, Sloan-C's emphasis on student and faculty acceptance as quality criteria is probably well-placed, while the European focus on creating a regulatory framework within which 
institutions from multiple nations can find common ground.

The work of the Sloan Consortium to date has been both pragmatic and challenging with respect to the quality of online learning. Its framework for quality fits well within the American system of accreditation and re-accreditation. It remains unclear to this author whether and how that work has made its way into the portfolio of concerns university presidents give time and attention to in the normal course of affairs.

At the same time, Sloan- $C$ could benefit substantially by expanding their discourse to include more of the sorts of concern represented by the activities of OECD and UNESCO. In addition, the "wary" but growing interest of some developing countries' universities suggests that Sloan-C might want to consider enlisting presidents and provosts of member institutions and organizations to host a session to which their peers from developing nations would be invited. E-learning, despite its "mainstream status", remains risky in the eyes of many university administrators, so hearing the good, the bad and the ugly of institutional initiatives in online learning from one’s colleagues might well quell presidential concerns.

\section{ABOUT THE AUTHOR}

Richard Skinner is the Senior Vice President for Programs and Research, Association of Governing Boards of Universities and Colleges, Washington DC - USA. He served as president and vice chancellor of Royal Roads University from 2002-2006.

\section{REFERENCES}

1. At least one Australian university is present in Canada and offering degrees, and Canada's Athabasca University is accredited in the U.S.

2. Centre for Educational Research and Innovation. Quality and Recognition in Higher Education: The Cross-Border Challenge Paris: 2004. http://213.253.134.29/oecd/pdfs/browseit/9604071E.PDF.

3. Middlehurst, R. Quality Assurance and Accreditation for Virtual Education: A discussion of models and needs. Paris: UNESCO, 2003. http://portal.unesco.org/education/en/file_download.php/a7e941e0c9287bb5f0371e59506479b1middl ehurst.doc.

4. The one serious attempt by an organization from a foreign country to offer courses and programs in the U.S. was that of the Open University, which closed its American operations in 2002 after two years of efforts.

5. Middlehurst, R. and C. Campbell. Quality Assurance and Cross-border Provision: Issues and Challenges. $2^{\text {nd }}$ Global Forum on International Quality Assurance, Accreditation and the Recognition of Qualifications: Paris, 2004.

6. Allen, I. E. and J. Seaman. Entering the Mainstream: The Quality and Extent of Online Education in the United States, 2003 ad 2004. Sloan-C: Needham, MA, 2004.

7. Ministry of Education, People's Republic of China. 2003-2007 Action Plan for Invigorating Education. Beijing, 2005.

8. Oblinger, D. "What Lessons Should We Take from E-commerce?” Conference: Costing and Financing Instructional Technologies in Higher Education: Practical Lessons and Policy Implications. Held in Herndon, Virginia, 2002.

9. WICHE and SREB have guidelines with explicit reference to student services. 